vibration of the buildings. The same tremulous motion was also felt in Victoria Road, Headingley, and no doubt in other parts of the town.

At Snaith and neighbourhood similar effects were produced. Mr. Barrett, the postmaster of that town, says the shock was so severe as to cause quite a noise with the goods on the shelves in his shop window vibrating, and he felt the floor under him shake distinctly. At 10.48 a.m. on Thursday morning an earthquake was distinctly felt at Thorne, Hatfield, Epworth, and Eastoft. At various parts of Thorne crockery and glass rattled upon the shelves in the houses, furniture was shifted, and many of the inhabitants were greatly alarmed by the floors slightly descending. At Hatfield Levels also some consternation was caused by the earthquake, which was felt very perceptibly. We have not heard of any damage being done by the shock.

About one o'clock on the morning of the I8th, northwestern Argyleshire was visited by an earthquake. The shock was distinctly felt at Ballachulish, and in many of the houses in the slate quarry district of Glencoe. The shock was felt with distinctness in Clachaig Inn, at the top of Glencoe. It travelled in a south-eastern direction.

Dr. Forel, of Morges, writes that a pretty strong shock was felt on the morning of June 20 , at 5.16 , in the cantons of Neuchâtel, Vaud, Berne, Fribourg, and Geneva, the seismic centre being probably the neighbourhood of the Lake of Neuchâtel. The intensity was No. IV. of the scale of seismic intensity.

\section{THE SCOTTISH MARINE STATION}

$\mathrm{T}$ $\mathrm{E}$ equipment of the Research Station at Granton, Edinburgh, has now been increased by the construction of a system of large tanks provided with a constant circulation of sea-water. These tanks are arranged very nearly according to the plan described in the account of the station and its work which was published in April last. The aquarium itself occupies the ground-floor of the building, whose upper story forms the biological laboratory, and it consists of seven large tanks, five of which are shallow, and two deep, the latter being provided with glass fronts. The pump, which is driven by a steamengine, the high-level reservoir, and the low-level reservoirs are situated at other parts of the premises. One of the deep tanks is being used for the study of the still mysterious life-history of Myxine glutinosa. Last week nearly I 50 specimens of that animal were brought alive to the station from the neighbourhood of St. Abb's Head, where it is very abundant. These were successfully domiciled in the aquarium. As out of three specimens brought alive to the "Ark" (the floating laboratory belonging to the station) on May I, and kept in a small glass aquarium about 15 inches long and 9 inches broad, two are still alive and healthy, there is good reason to hope that there will be no difficulty in keeping a large number alive for any length of time in a tank about 7 feet by 5 feet by 4 feet, which are the dimensions of the one now used for the purpose. It was found in the former experiment that the Myxine when left to themselves, burrowed into the layer of mud which had been placed at the bottom of the small aquarium, and lay for hours motionless, their bedies, with the exception of the extreme tip of the snout, being entirely buried. The snout is protruded for the purpose of respiration, a current of water passing constantly through the nostril into the œesophagus, and escaping at the two respiratory apertures. The normal condition of the animal when not actively engaged in the search for food is evidently to lie thus buried in mud. It is well known to fishermen, at least to those who are employed in line-fishing, that eellets, as Myxine are called by them, are met with almost exclusively on muddy ground. At the place where the creatures are more abundant than anywhere else in the neighbourhood of the Firth of Forth, namely, off St. Abb's Head, the sea-bottom throughout an extensive area consists of soft black mud. A quantity of this mud was brought to the station with the living specimens, and a layer of it 6 or 8 inches in depth placed at the bottom of the tank in which the Myxine were to be kept. The animals are now thickly scattered through the layer of mud, like earthworms in garden soil.

Some of the shallow tanks are being used for the studv of the reproduction of the oyster. Supplies of oysters are being obtained from various sources, and before long a series of experiments as to the conditions necessary to the life of the oyster larvæ will be carried out. It is hoped, as the least result from this work, that new interest will be aroused in this country in the question of the scientific artificial cultivation of oysters.

The opportunities afforded for research by the laboratory and new aquarium cannot be fully utilised by those now working at the Station, and biologists who would come and carry out original work at the Station would be gladly welcomed.

A temporary branch of the station is now being organised at Millport, on the Firth of Clyde. It will be open during the months of July and August. The floating laboratory known as the "Ark" will be moored next week in still water off one of the small islands in the Bay of Millport, and the yacht Medusa will be stationed there for the purpose of dredging and providing material for study. Several naturalists have mad e arrangements to carry on work at Millport during part or whole of the time that the "Ark" will be there : amongst others the Rev. A. M. Norman, Prof. W. A. Herdman, of University College, Liverpool, Mr. David Robertson, of Glasgow; Mr. J. Harvey Gibson, Mr. J. R. Henderson. Mr. John Murray, convener of the Committee, entrusted with the management of the Scottish Marine Station, will be at Millport during the greater part of the time. It is hoped that one result of the work will be the preparation of an account of the fauna of the Firth of Clyde which will include, besides the results of the investigations to be carried on, the results of the previous work in the same field. As several of the experienced naturalists mentioned above are already familiar with the fauna of the Firth, a publication on the subject produced by their cooperation will be complete and authoritative. Any naturalists who may wish to carry on research at the Millport temporary station are invited to communicate with Mr. John Murray.

\section{J. T. CUNNINGHAM}

COMPOSITE PORTRAITS OF MEMBERS OF THE NATIONAL ACADEMY OF SCIENCES

THOSE of the members who were present at the Washington meeting of the Academy last spring will remember that, at the request of Prof. Brewer and myself, they sat for their separate photographed portraits for the purpose of obtaining an experimental composite picture. Prof. Baird kindly offered the facilities of the photographic department; and the pictures taken by Mr. Smilie, the photographer in charge, bear the same stamp of excellence that characterises so generally the work of that department of the National Museum.

As only one or two previous attempts, I believe, have been made to produce composites in this country, I will state briefly what they are, and how they are made.

The idea in its broadest sense was conceived and applied by Francis Galton for the purpose of obtaining an average or type portrait-i.e. a picture that should show the features that are common to a group of individuals, and exclude those that are purely individual. It is clear that, in proportion as this result is attainable, the method will be of value in obtaining a clear conception of the external characteristics of any given type or class.

1 From Science, to the editor of which we are also indebted for the use of the photographic plate accompanying the article. 
Galton reminds us that, during the first days of a traveller's meeting with a very different race, he finds it impossible to distinguish one from another, without making a special effort to do so: to him the whole race looks alike, excepting distinctions of age and sex. The reason of this is that, by short contacts with many individuals, he receives upon his retina, and has recorded upon his memory, a composite picture emphasizing only what is common to the race, and omitting the individualities. This also explains the common fact that resemblances among members of a family are more patent to strangers than to the relatives.

The individuals entering into these composites were all photographed in the same position. Two points were marked on the ground glass of the camera; and the in. strument was moved at each sitting to make the eyes of the sitter exactly coincident with these points. The composites were made by my assistant, Mr. B. T. Putnam, who introduced the negatives successively into an apparatus carefully constructed by himself, and essentially like that designed by Mr. Galton, where they were photographed by transmitted light. The arrangements of the conditions of light, \&c., were such that an aggregate exposure of sixty-two seconds would be sufficient to take a good picture. What was wanted, however, was not an impression of one portrait on the plate, but of all the thirty-one ; and to do this required that the aggregate exposure of all the thirty-one should be sixty-two seconds, or only two seconds for each. Now, an exposure of two seconds is, under the adopted conditions, too short to produce a perceptible effect. It results from this, that only those features or lines that are common to all are perfectly given, and that what is common to a small number is only faintly given, while individualities are imperceptible. The greater the physical resemblances among the individuals, the better will be the composites. A composite of a family or of near relatives, where there is an underlying sameness of features, gives a very sharp and individual-looking picture.

It would be difficult to find thirty-one intelligent men more diverse among themselves as regards facial likeness than the academicians entering into this composite. They are a group selected as a type of the higher American intelligence in the field of abstract science, all but one or two being of American birth, and nearly all being of American ancestry for several generations. The faces give to me an idea of perfect equilibrium, of marked intelligence, and, what must be inseparable from the latter in a scientific investigator, of imaginativeness. The expression of absolute repose is doubtless due to the complete neutrality of the portraits.

Fig. 3 contains eighteen naturalists and thirteen mathematicians, whose average age is about 52 years. Fig. I contains twelve mathematicians, including both astronomers and physicists, whose average age is about $5 I_{3}^{2}$ years. Fig. 2 is a composite of sixteen naturalists, including seven biologists, three chemists, and six geologists, with an average age of about $52 \frac{1}{2}$ years.

I may mention, as perhaps only a remarkable coincidence, that the positives of the mathematicians, and also of the thirty-one academicians, suggested to me at once forcibly the face of a member of the Academy who belongs to a family of mathematicians, but who happened not to be among the sitters for the composite. In the prints this resemblance is less strong, but in these it was observed quite independently by many members of the Academy. So, also, in the positive of the naturalists, the face suggested, also quite independently to myself and many others, was that of a very eminent naturalist, deceased several years before the sitting for this composite.

There is given also a composite (Fig. 4) of a differently selected group. It is of twenty-six members of the Corps of the Northern Transcontinental Survey-an organisa- tion of which I had charge, and the object of which was an economic survey of the North-Western Territories. It was a corps of men carefully selected as thoroughly trained in their respective departments of applied geology, topography, and chemistry, and having the physique and energy, as well as intelligence, needed to execute such 'a task in face of many obstacles. The average age of this group was 30 years.

RAPHAEL PUMPELLY

\section{HOW THE NORTH-NORWAY FFORDS WERE $M A D E$}

I N NATURE (vol. xxx. p. 202) there was published an article by me "On Northern Norway under the Glacial Age," in which, among other subjects, I referred to the course of the travelled granite blocks in the neighbourhood of Tromsö. The researches I had then made in this direction were, however, confined to a limited area, whilst last summer I was able to extend the same to the point whence the blocks started. Although one of my assumptions in the former article has not been confirmed by my last researches, the conclusions I then arrived at have in the main been corroborated. And as I believe that this subject is one of considerable importance to science, I venture to give an account of my last researches.

In order to understand the subject, it is necessary to explain the orographical conditions along the course of the travelled blocks from the Swedish frontier to the Arctic Ocean.

From the eastern end of the Alt Lake, near the Swedish frontier, and northwards to the Store Rosta Lake, the country on the Norwegian side assumes the form of an extensive alpine plateau, with broad depressions, the average height of which is about 2000 feet, running between low rounded ridges. In the south-eastern part of these plateaux, not far from the eastern end of the Alt Lake, the Divi River rises. Having for some Io graphical English miles followed the plateau, this river flows gradually towards the Divi Valley, which it enters and follows throughout its whole course in a northeasterly direction, flowing eventually into the Maals River at a height of 260 feet $(82 \mathrm{~m}$.) above sea-level. Its length, from where it leaves the plateau, to the spot where it joins the Maals River, is about 30 geographical miles. In its upper course, where the Maals River receives the Divi River, the former flows through a wide plain or low plateau, the so-called Överbygd, which gradually slopes down to a distinct valley, the Maals Valley proper, which runs in a westerly direction along the southern slope of the high, island-shaped mountain ridge called Mauken. The latter begins about 5 miles west of the spot where the Divi River enters the Maals River, whence it runs in a direction east-west for a length of about 15 geographical miles, the highest tops being upwards of 4000 feet ( $1255 \mathrm{~m}$.). On the north-western side, however, the Överbygd gradually rises towards the broad mountain depression filled by the Tag Lake, 7 miles in length, which runs in a direction east-west along the northern slope of Mauken, viz. between the latter and the more northerly-lying ridge Omasvarre, which, with tops upwards of I 900 feet $(596 \mathrm{~m}$.) in height, also runs in a direction east-west. The bottom of this depression is filled with the imposing Tag Lake, which lies on a height of about 600 to 700 feet (188 to $220 \mathrm{~m}$.) above sea-level, and thus about 400 feet (I20 m.) higher than the Divi River at the spot where it enters the Maals River. At the western end of the Tag Lake this depression takes the form of a broad mountain basin, the so-called Tag Valley, which in a north-easterly direction descends to Balsfjord. The distance between the Tag Lake and the Balsfjord is about Io geographical miles. The Tag Valley is, on the western side, bordered by the lofty Maartin peaks, and further to the north-east by the Slet 